\title{
Structural Reorganization of Allyl Isothiocyanate into Pyrrole Ring under Superbase: A Straightforward Access to NH-2-(Alkylsulfanyl)-1H-pyrroles and $N$-Alkyl-2-(alkylsulfanyl)-1 $H$-pyrroles
}

\author{
Nina A. Nedolya, ${ }^{\text {a }}$ Lambert Brandsma, ${ }^{b}$ Boris A. Trofimov*a \\ a A. E. Favorsky Irkutsk Institute of Chemistry of the Russian Academy of Sciences, Siberian Branch, Favorsky Street 1, 664033 Irkutsk, \\ Russian Federation \\ Fax +7(3952)419346; E-mail: boris_trofimov@irioch.irk.ru \\ b Julianalaan 273, 3722 GN Bilthoven, The Netherlands \\ Received: 02.09.2012; Accepted after revision: 07.11.2012
}

\begin{abstract}
A novel and facile synthetic route to NH-2-(alkylsulfanyl)- $1 H$-pyrroles and $N$-alkyl-2-(alkylsulfanyl)- $1 H$-pyrroles is reported. This was achieved by deprotonation of allyl isothiocyanate with the superbasic pair lithium diisopropylamide and potassium tert-butoxide (1:1 molar mixture), followed by intramolecular ring closure, deprotonation of cyclic anion with a second equivalent of the superbase, and final sequential N-protolysis/S-alkylation or $\mathrm{N}, \mathrm{S}$-dialkylation of the formed N,S-centered pyrrol-2-ylsulfide dianion.
\end{abstract}

Key words: 2-(alkylsulfanyl)-substituted pyrroles, allyl isothiocyanate, superbases, deprotonation, cyclization, alkylation

Pyrroles, in general, ${ }^{1}$ and those with an organosulfur group, in particular, ${ }^{2-8}$ represent a very important and practically useful class of N-heterocycles. The introduction of sulfur-containing substituents into aromatics, including pyrroles and their derivatives, is of current interest $^{3}$ because their reactivity, bioactivity, physical, material, and other properties, as well as synthetic and therapeutic potential can be profoundly altered. ${ }^{2,4}$ It was also shown that electron-rich alkylsulfanyl substituents or their oxidized derivatives (alkyl sulfoxides and sulfones) can serve as effective and perspective protecting groups for the 2-position of the pyrrole ring. ${ }^{2 \mathrm{~h}, 5}$ Therefore, a novel practical method for the synthesis of such compounds is of great interest in synthetic organic chemistry. Among the known methods for the synthesis of multisubstituted 2-(alkylsulfanyl)pyrroles from acyclic precursors, ${ }^{6,7}$ the methodology using isothiocyanates both as a structural fragment of pyrrole core and supplier of sulfur atom for sulfa-substituents seems to be the most powerful, simple, and perspective. Thus, the combination of different isothiocyanates (alkyl, cycloalkyl, alkoxyalkyl, aryl) with allenic or acetylenic carbanions, generated in situ from the corresponding allenes or alkynes, affords 1,3-di-, 1,5-di-, or 1,3,5-trisubstituted 2-(alkylsulfanyl)pyrroles in good to excellent yields in one preparative step. ${ }^{7}$ However, these approaches $^{6,7}$ are unsuitable for the synthesis of $1,3,4,5$ unsubstituted 2-(alkylsulfanyl)pyrroles that are applied in the synthesis of porphyrinic macrocycles and related com-

SYNTHESIS 2013, 45, 0093-0100

Advanced online publication: 26.11.2012

DOI: 10.1055/s-0032-1316819; Art ID: SS-2012-Z0700-OP

(C) Georg Thieme Verlag Stuttgart · New York pounds as well as important synthetic intermediates and versatile building blocks. ${ }^{2 \mathrm{~d}, \mathrm{~h}, 4 \mathrm{e}, 5 \mathrm{a}, \mathrm{b}}$ Most of the traditional methods for the preparation of these pyrroles are based on utilization of preexisting pyrrole rings. To the 2-position of the latter, alkylsulfanyl groups have been introduced by different but usually multistep ways. ${ }^{4 \mathrm{f}, 5 \mathrm{c}, 8}$ Moreover, the yields of the pyrroles are often rather low even at the final step of the synthesis. Recalculation of the yields taking into account those on all stages of the process makes the known methods synthetically even less attractive because of moderate or low overall yields. Also, to the best of our knowledge no publication is known in the literature describing the synthesis of representative numbers of N-substituted and N-unsubstituted 2-(alkylsulfanyl)-1Hpyrroles by some general method from a common raw material.

Following our strategy based on the use of isothiocyanate/organometallics systems for the construction of the most of fundamental heterocycles carrying sulfa-substituents, ${ }^{9}$ including 2-(alkylsulfanyl)pyrroles, ${ }^{7}$ we now report the very simple synthesis of 1,3,4,5- and 3,4,5-unsubstituted 2-(alkylsulfanyl)pyrroles through the superbase-induced structural reorganization of commercially available allyl isothiocyanate into pyrrole ring.

Earlier we have shown that treatment of methyl isothiocyanate with the system $\mathrm{LDA} / t$-BuOK (potassium diisopropylamide) leads to 1-methyl-2,5-bis(methylsulfanyl)- $1 H$ imidazole (1) in good yield (Scheme 1). ${ }^{10}$

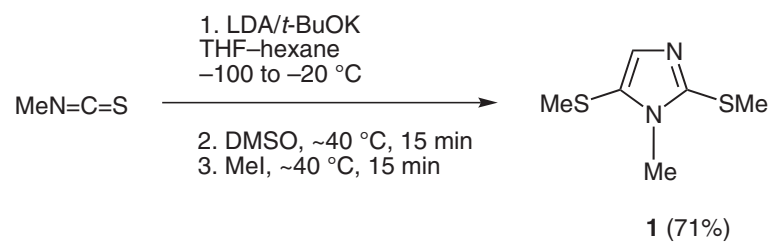

Scheme 1 Synthesis of imidazole 1 via deprotonation and dimerization of methyl isothiocyanate

In an attempt to prepare the imidazole derivative $\mathbf{2}$ from allyl isothiocyanate under conditions similar to those leading to the formation of imidazole $\mathbf{1}$ from methyl isothiocyanate, the former was reacted with the system $\mathrm{LDA} / t$-BuOK in the presence of DMSO (as a co-solvent). However, we were surprised to find that instead of the ex- 
pected imidazole 2, $N$-methyl-2-(methylsulfanyl)- $1 H$ pyrrole (3a) was formed in $\sim 30 \%$ yield, along with a number of volatile and nonvolatile products (Scheme 2). ${ }^{11}$ The product 3a was identical with the sample, prepared by the known reaction of $\alpha$-metalated $N$-methyl-1H-pyrrole with dimethyl disulfide ${ }^{12}$ (Scheme 2).

Further investigation of the reaction of allyl isothiocyanate with superbases have shown that treatment of allyl isothiocyanate with LDA (without $t$-BuOK) led to thiazole 4 in $75 \%$ yield (via deprotonation, addition of formed carbanion to a second molecule of isothiocyanate, cyclization, deprotonation of thiazolyl anion by a second molecule of superbase, and final N,S-dialkylation) (Scheme 2). ${ }^{13}$ In attempts to deprotonate allyl isothiocyanate with potassium tert-butoxide (without LDA) the azadienic compound 5 was obtained in moderate yield (Scheme 2). The main reaction in this case was the addition of $t$ - $\mathrm{BuOK}$ to $\mathrm{N}=\mathrm{C}=\mathrm{S}$ function, followed by S-methylation of the initial adduct and base-catalyzed migration of the double bond in allylimine fragment. When $t$-BuOK was added after the interaction between allyl isothiocyanate and LDA, only nonvolatile products were found. Hence the combination of two superbases - lithium organylamide and alkali metal alkoxide (for instance, LDA and $t$-BuOK, as was found originally) - is strongly required to direct the reaction in the direction of pyrrole ring formation. We have also shown that the use of DMSO in the pyrrole synthesis does not give significant advantages over reactions, carried out in its absence.

These studies have resulted in the development of a novel synthetically valuable method of the one-pot synthesis of
$\mathrm{N}$-alkyl-2-(alkylsulfanyl)-1H-pyrroles $\mathbf{3 a - d}$ and $\mathrm{NH}-2-$ (alkylsulfanyl)-1H-pyrroles 6a-f, including earlier unknown representatives, through transformations of allyl isothiocyanate under action of two equivalents of LDA/ $t$-BuOK system (1:1 molar mixture) in THF-hexane followed by N,S- or S-alkylation with alkyl halides or dialkyl sulfates (Table 1).

Based on the experimental facts mentioned, the formation of the pyrrole core can be explained by assuming an electrocyclization of the primarily generated anion 7, followed by a fast deprotonation of cyclic anion $\mathbf{8}$ with a second equivalent of basic reagent resulting in the N,Scentered pyrrolyl dianion 9. Final alkylation of dianionic species 9 with excess or, at least, with two equivalents of alkyl iodide or dialkyl sulfate leads to $N$-alkyl-2-(alkylsulfanyl)-1 $H$-pyrroles 3 (Scheme in Table 1).

Several experiments on the effect of varying the temperature as well as the nature and amount of superbase were carried out. Reasonable isolated yields (between 54 and $71 \%)$ of pyrroles $3(\mathrm{R}=$ alkyl) were obtained when a solution of allyl isothiocyanate in THF was added dropwise (over 30-60 $\mathrm{min}$ ) to a solution of two equivalents of the 1:1 molar mixture of LDA and $t$-BuOK in THF-hexane at temperatures in the range of -40 to $-20^{\circ} \mathrm{C}$. When allyl isothiocyanate was added to the base at ca. $-70{ }^{\circ} \mathrm{C}$ or lower temperatures, mainly the thiazole $\mathbf{4}$ was detected in the crude product. Similar results were also obtained, when the reaction was carried out at ca. $-70{ }^{\circ} \mathrm{C}$ in the presence of HMPT. In all the cases, the content of pyrrole 3a in the crude product was $\sim 15-20 \%$ (GC).

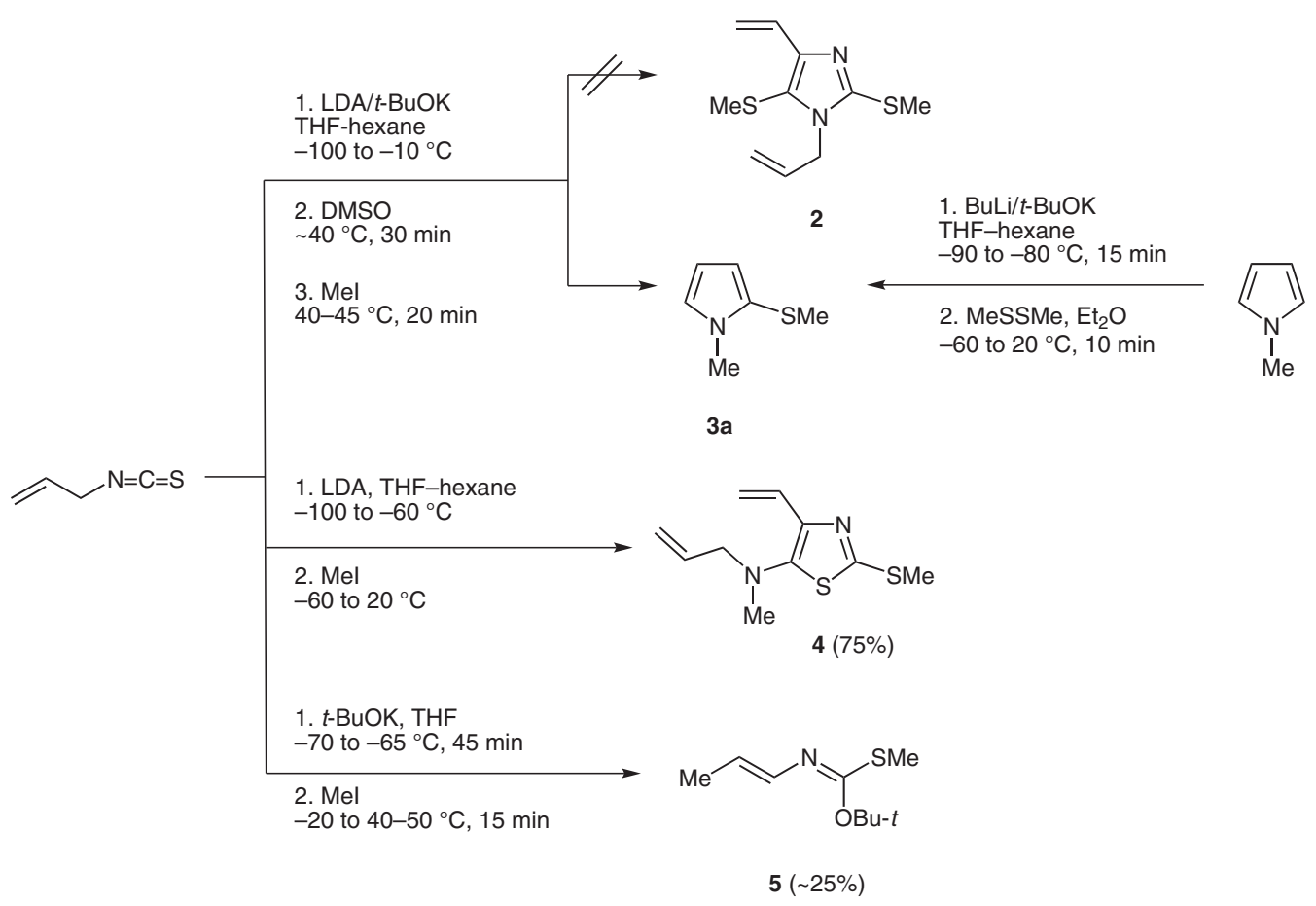

Scheme 2 Synthesis of compounds 3a, 4, and $\mathbf{5}$ via reactions of allyl isothiocyanate with superbases 
Table 1 Synthesis of $N$-Alkyl-2-(alkylsulfanyl)-1 $H$-pyrroles 3a-d and NH-2-(alkylsulfanyl)-1 $H$-pyrroles 6a-f via Structural Reorganization of Allyl Isothiocyanate under Superbase

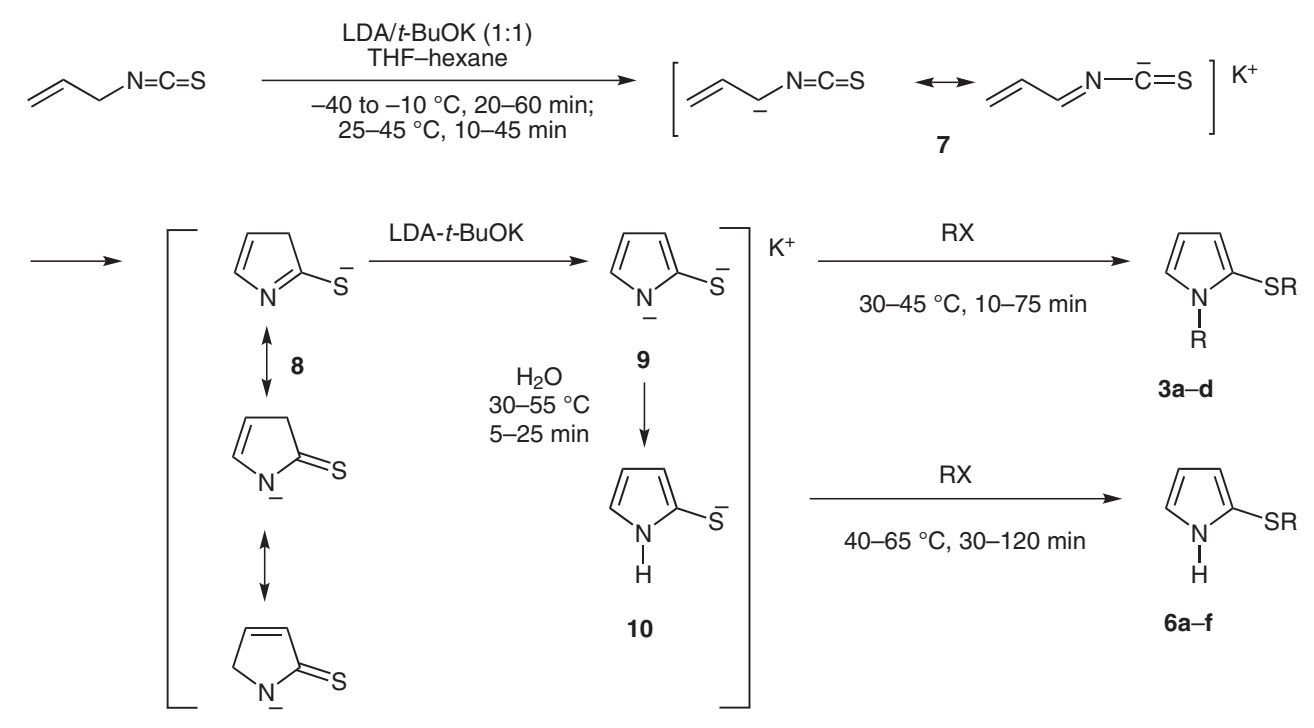

$\mathrm{R}=\mathrm{Me}(\mathbf{a}), \mathrm{Et}(\mathbf{b}), n-\operatorname{Pr}(\mathbf{c}), n-\mathrm{Bu}(\mathbf{d}), \mathrm{CH}_{2}=\mathrm{CHCH}_{2}(\mathbf{e}), \mathrm{HC} \equiv \mathrm{CCH}_{2}(\mathbf{f}) ; \mathrm{X}=\mathrm{Br}, \mathrm{I}, \mathrm{RSO}_{4}$

3d 3

a After distillation.

${ }^{\mathrm{b}}$ Intermediate 9 was at first quenched with water and then with an alkylating agent (method A).

${ }^{\mathrm{c}}$ Water was not used; alkyl iodide (1 equiv) was added dropwise (method B) (Scheme 3).

Use of three equivalents of $\mathrm{LDA} / t$ - $\mathrm{BuOK}$ did not demonstrate any notable influence on the reaction course or the pyrrole yields. Under similar conditions (with 2 equiv of the base) the yields of pyrrole $3 \mathbf{a}$ were comparable. Realization of the reaction with one equivalent of the same base also gave pyrrole 3a but the yield was in the range of $30-40 \%$. This result is consistent with the mechanism (scheme in Table 1) requiring two equivalents of the su- perbase for the formation of pyrrole ring from allyl isothiocyanate.

Experiments carried out with $\mathrm{LDA} / t-\mathrm{BuONa}$ gave a somewhat lower yield than with $\mathrm{LDA} / t-\mathrm{BuOK}$, but nevertheless with significantly high yield $(\sim 52 \%)$ of pyrrole $3 \mathbf{a}$. The reaction of allyl isothiocyanate with 1:1 molar combination of $\mathrm{LDA} / t$-AmOCs followed by alkylation furnished 2-(alkylsulfanyl)- $1 H$-pyrroles in yields that were a 
little (by 5 to $10 \%$ ) higher than those obtained with $\mathrm{LDA} / t$-BuOK. But $t$-AmOCs is not a cheap and easily accessible base and for this reason could not be more preferable than the commercial $t$-BuOK as a component of superbasic system for the reaction.

The more interesting and important pyrrole derivatives 6 could be obtained in yields varying from $\sim 47$ $\left(\mathrm{R}=\mathrm{CH}_{2} \mathrm{C} \equiv \mathrm{CH}\right)$ to $\sim 58-68 \%(\mathrm{R}=$ alkyl, allyl) by adding a certain amount of water prior to performing the alkylation of intermediate 9 (method A, Table 1). The yields of the pyrrole derivatives $\mathbf{6}$ are not very high, but it should be pointed out that our direct method is preferred over the multistep route for NH-2-substituted pyrroles, which involves N-protection of the pyrrole, treatment of the Nprotected compound with two equivalents of $n$ - $\mathrm{BuLi}$, reaction with an electrophilic reagent at the 2-position, and deprotection. ${ }^{14}$

At least pyrroles $\mathbf{6 c}$ and $\mathbf{6 d}$ can also be obtained in moderate to good yields without the use of water before alkylation. For this, one equivalent of the corresponding alkyl iodide was added dropwise to the reaction mixture (method B) (Scheme 3).

Comparison of these procedures for the synthesis of above mentioned pyrroles 6 did not reveal the advantages of one technique over another. For instance, in the case of pyrrole $6 \mathrm{c}(\mathrm{R}=n-\mathrm{Pr})$ its yield was higher, $68 \%$ against $54 \%$, when alkylating agent (propyl iodide) was added dropwise to the reaction mixture (without preliminary quenching with water). But in the case of pyrrole $\mathbf{6 d}(\mathrm{R}=n-\mathrm{Bu})$, on the contrary, the yield was higher, $68 \%$ against $46 \%$, when the reaction mixture was treated with some amount of water before alkylation with butyl iodide. Similar to alkyl iodides, alkyl bromides can be used as alkylating agents.

The structures of the products have been assigned using IR, ${ }^{1} \mathrm{H},{ }^{13} \mathrm{C}$, and heteronuclear $2 \mathrm{D}\left({ }^{1} \mathrm{H}-{ }^{-13} \mathrm{C}\right.$ HMBC $) \mathrm{NMR}$ spectroscopy, and mass spectrometry.

The synthetic usefulness of the present approach to NH-2(alkylsulfanyl)-1 $H$-pyrroles received recently experimental confirmation. Namely, our procedure for 2-(methylsulfanyl)- $1 H$-pyrrole synthesis, described earlier in a short communication, ${ }^{11 a}$ was used in a multistep synthesis of regiospecifically $\alpha-{ }^{13} \mathrm{C}$-labeled porphyrins for studies of ground-state hole transfer in multiporphyrin arrays. ${ }^{5 a}$
In conclusion, a new efficient strategy of the pyrrole ring construction via an unprecedented reorganization of commercially available allyl isothiocyanate under the action of LDA/potassium tert-butoxide system in THF-hexane opens a novel and very simple approach to synthetically and pharmacologically promising $\mathrm{N}$-substituted and $\mathrm{N}$ unsubstituted 2-(alkylsulfanyl)-1 $H$-pyrroles. Advantages of this methodology providing a new short one-pot synthesis of 2-(alkylsulfanyl)-substituted pyrroles compared with those described in the literature (mostly via multistep sulfanylation of preexisting pyrrole core $)^{8}$ are evident.

Synthetic potential of this approach for the construction of pyrrole ring bearing alkylsulfanyl substituent at 2-position from easily accessible allyl isothiocyanate is not certainly limited to the described examples. Successful introduction of other electrophiles in this reaction also seems possible and will be reported elsewhere.

Allyl isothiocyanate, $n$-BuLi (1.6 M solution in hexane), $t$-BuOK, $i-\mathrm{Pr}_{2} \mathrm{NH}$, alkylating agents, and solvents are commercially available. All solvents were purified and dried according to standard procedures. All reactions were performed under anhydrous conditions and in a $\mathrm{N}_{2}$ atmosphere. For all reactions at low temperatures a cooling bath with liquid $\mathrm{N}_{2}$ was used. All reactions were monitored by $\mathrm{GC}$ and ${ }^{1} \mathrm{H}$ NMR analyses.

IR spectra were measured neat on a Specord IR-75 spectrophotometer. The NMR spectra were recorded on Bruker DPX-400, Bruker AV-400 [400.13 $\left.\left({ }^{1} \mathrm{H}\right), 100.62 \mathrm{MHz}\left({ }^{13} \mathrm{C}\right)\right]$, and Varian EM-390 [90 $\left.\mathrm{MHz}\left({ }^{1} \mathrm{H}\right)\right]$ spectrometers in $\mathrm{CDCl}_{3}$ and $\mathrm{CCl}_{4}$ solutions, respectively, at r.t., referenced to HMDS and TMS as internal standards. Assignments of spectra were carried out using $2 \mathrm{D}$ experiments. The mass spectra (EI, $60 \mathrm{eV}$ ) were recorded on a LKB-2091 instrument. $\mathrm{GC}$ analyses were carried out on a Varian 3400 gas chromatograph (15 m capillary column coated with a $1.5 \mu \mathrm{DB}-5$, internal diameter $0.53 \mathrm{~mm}$ ). The microanalyses were performed on a Flash EA 1112 Series elemental analyzer.

\section{$\mathrm{N}$-Methyl-2-(methylsulfanyl)-1H-pyrrole (3a); Typical Proce- dure}

To a stirred solution of $i-\mathrm{Pr}_{2} \mathrm{NH}(13 \mathrm{~g}, 0.13 \mathrm{~mol})$ and $t-\mathrm{BuOK}(22 \mathrm{~g}$, $0.20 \mathrm{~mol})$ in THF $(60 \mathrm{~mL})$ under $\mathrm{N}_{2}$, at ca. $-50{ }^{\circ} \mathrm{C}$ was added a solution of $n$-BuLi $(0.12 \mathrm{~mol})$ in hexane $(72 \mathrm{~mL})$. A solution of allyl isothiocyanate $(5.4 \mathrm{~g}, 0.05 \mathrm{~mol})$ in THF $(55 \mathrm{~mL})$ was added dropwise over $30 \mathrm{~min}$ while keeping the temperature of the solution between -40 and $-20^{\circ} \mathrm{C}$. After the addition, the reaction mixture was stirred for $15 \mathrm{~min}$ at $25^{\circ} \mathrm{C}$ and then cooled to $-40{ }^{\circ} \mathrm{C}$. Then, dimethyl sulfate $(25 \mathrm{~g}, 0.20 \mathrm{~mol})$ was added in one portion, and the reaction mixture was heated for $10 \mathrm{~min}$ at $30-35^{\circ} \mathrm{C}$. Ice-water $(80 \mathrm{~mL})$ was then added and the product was extracted with pentane $(2 \times 30 \mathrm{~mL})$ and $\mathrm{Et}_{2} \mathrm{O}(2 \times 30 \mathrm{~mL})$. The combined organic extracts were washed with $\mathrm{H}_{2} \mathrm{O}(3 \times 40 \mathrm{~mL})$, dried $\left(\mathrm{K}_{2} \mathrm{CO}_{3}\right)$, and concentrated under re-

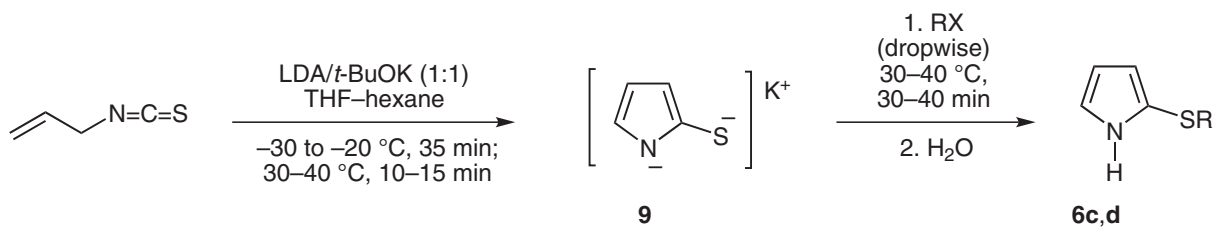

6c: $\mathrm{R}=n-\operatorname{Pr}, 68 \% ; 6 \mathrm{~d}: \mathrm{R}=n-\mathrm{Bu}, 46 \%$

Scheme 3 Synthesis of NH-pyrroles $\mathbf{6 c}, \mathbf{d}$ via dropwise addition of one equivalent of alkylating agent to intermediate 9 
duced pressure. Distillation of the remaining liquid through a $20 \mathrm{~cm}$ Vigreux column gave the pyrrole $\mathbf{3 a}$ as a light-yellow liquid; yield: $3.9 \mathrm{~g}(61 \%)$; bp $111-115^{\circ} \mathrm{C} / 3$ Torr; $n_{\mathrm{D}}{ }^{20} 1.5480$ (Lit. ${ }^{12}$ bp $70{ }^{\circ} \mathrm{C} / 15$ $\left.\mathrm{mmHg}, n_{\mathrm{D}}{ }^{21} 1.5496\right)$.

IR (neat): 3100, 2960, 2910, 2850, 1510, 1460, 1430, 1410, 1310, $1300,1200,1090,1050,1000,970,790,720,680,600 \mathrm{~cm}^{-1}$.

${ }^{1} \mathrm{H}$ NMR $\left(90 \mathrm{MHz}, \mathrm{CCl}_{4}\right): \delta=2.18\left(\mathrm{~s}, 3 \mathrm{H}, \mathrm{SCH}_{3}\right), 3.64(\mathrm{~s}, 3 \mathrm{H}$, $\left.\mathrm{NCH}_{3}\right), 5.95$ (m, $\left.1 \mathrm{H}, \mathrm{H}-4\right), 6.18$ (m, $\left.1 \mathrm{H}, \mathrm{H}-3\right), 6.58$ (m, $\left.1 \mathrm{H}, \mathrm{H}-5\right)$. MS (EI, $60 \mathrm{eV}): m / z(\%)=127\left(100,[\mathrm{M}]^{+}\right)\left(\right.$Lit. $\left.^{15}\right)$.

Anal. Calcd for $\mathrm{C}_{6} \mathrm{H}_{9} \mathrm{NS}$ : C, 56.65; H, 7.13; N, 11.01; S, 25.20 . Found: C, 56.71; H, 7.08; N, 11.15; S, 25.10.

\section{$\mathrm{N}$-Ethyl-2-(ethylsulfanyl)- $1 \mathrm{H}$-pyrrole (3b)}

To a solution of $i-\mathrm{Pr}_{2} \mathrm{NH}(16.1 \mathrm{~g}, 0.16 \mathrm{~mol}), t$-BuOK $(16.2 \mathrm{~g}, 0.14$ $\mathrm{mol})$, and $n$-BuLi $(0.15 \mathrm{~mol})$ in THF $(60 \mathrm{~mL})$ and hexane $(92 \mathrm{~mL})$ was added dropwise a solution of allyl isothiocyanate $(5.4 \mathrm{~g}, 0.05$ $\mathrm{mol})$ in THF $(70 \mathrm{~mL})$ during $60 \mathrm{~min}$ at -40 to $-30{ }^{\circ} \mathrm{C}$. After stirring for $10 \mathrm{~min}$ at $35^{\circ} \mathrm{C}$, EtI $(26.2 \mathrm{~g}, 0.17 \mathrm{~mol})$ was added in one portion at $-10^{\circ} \mathrm{C}$, and the reaction mixture was stirred for $30 \mathrm{~min}$ at $\sim 45^{\circ} \mathrm{C}$. Workup as described above afforded $\mathbf{3 b}$ as a light-yellow liquid; yield: $4.2 \mathrm{~g}(54 \%)$; bp $\sim 40{ }^{\circ} \mathrm{C} / 0.7$ Torr; $n_{\mathrm{D}}{ }^{20} 1.5148$.

IR (neat): $3100,2965,2920,2860,1510,1450,1435,1370,1350$, $1280,1260,1200,1120,1100,1080,1060,1040,1030,1000,965$, $950,880,790,760,720,660,610 \mathrm{~cm}^{-1}$

${ }^{1} \mathrm{H}$ NMR (400 MHz, $\left.\mathrm{CDCl}_{3}\right): \delta=1.15\left(\mathrm{t}, J=7.4 \mathrm{~Hz}, 3 \mathrm{H}, \mathrm{CH}_{3}\right)$, $1.32\left(\mathrm{t}, J=7.2 \mathrm{~Hz}, 3 \mathrm{H}, \mathrm{CH}_{3}\right), 2.54\left(\mathrm{q}, J=7.4 \mathrm{~Hz}, 2 \mathrm{H}, \mathrm{SCH}_{2}\right), 4.02$ (q, $\left.J=7.2 \mathrm{~Hz}, 2 \mathrm{H}, \mathrm{NCH}_{2}\right), 6.10(\mathrm{~m}, 1 \mathrm{H}, \mathrm{H}-4), 6.31(\mathrm{~m}, 1 \mathrm{H}, \mathrm{H}-3)$, $6.76(\mathrm{~m}, 1 \mathrm{H}, \mathrm{H}-5)$.

${ }^{13} \mathrm{C} \mathrm{NMR}\left(\mathrm{CDCl}_{3}\right): \delta=14.73\left(\mathrm{CH}_{3}\right), 17.02\left(\mathrm{CH}_{3}\right), 31.66\left(\mathrm{SCH}_{2}\right)$, $41.41\left(\mathrm{NCH}_{2}\right), 108.14$ (C-4), 117.58 (C-3), 120.21 (C-2), 122.66 (C-5).

The ${ }^{1} \mathrm{H}-{ }^{13} \mathrm{C}$ HMBC $2 \mathrm{D}$ experiment provided additional support for the proposed structure.

MS (EI, $60 \mathrm{eV}): m / z(\%)=155\left(67,[\mathrm{M}]^{+}\right)\left(\right.$Lit. $\left.^{15}\right)$.

Anal. Calcd for $\mathrm{C}_{8} \mathrm{H}_{13} \mathrm{NS}$ : C, 61.89; H, 8.44; N, 9.02; S, 20.65 . Found: C, 61.73; H, 8.55; N, 8.92; S, 20.87.

\section{$\mathrm{N}$-Propyl-2-(propylsulfanyl)-1 $\mathrm{H}$-pyrrole (3c)}

To a solution of $i$ - $\mathrm{Pr}_{2} \mathrm{NH}(13.9 \mathrm{~g}, 0.14 \mathrm{~mol}), t$-BuOK $(13.3 \mathrm{~g}, 0.12$ $\mathrm{mol})$, and $n$-BuLi $(0.12 \mathrm{~mol})$ in THF $(60 \mathrm{~mL})$ and hexane $(72 \mathrm{~mL})$ was added dropwise a solution of allyl isothiocyanate $(5.4 \mathrm{~g}, 0.05$ $\mathrm{mol})$ in THF $(35 \mathrm{~mL})$ during $30 \mathrm{~min}$ at -30 to $-25^{\circ} \mathrm{C}$. After stirring for $10 \mathrm{~min}$ at $35-38{ }^{\circ} \mathrm{C}, n$-PrI $(25.9 \mathrm{~g}, 0.15 \mathrm{~mol})$ was added in one portion at $8{ }^{\circ} \mathrm{C}$, and the reaction mixture was stirred for $75 \mathrm{~min}$ at $\sim 40^{\circ} \mathrm{C}$. Workup as described above afforded $\mathbf{3 c}$ as a light-yellow liquid; yield: $5.3 \mathrm{~g}(58 \%)$; bp $\sim 70{ }^{\circ} \mathrm{C} / 0.5$ Torr; $n_{\mathrm{D}}{ }^{20} 1.5208$.

${ }^{1} \mathrm{H}$ NMR $\left(400 \mathrm{MHz}, \mathrm{CDCl}_{3}\right): \delta=0.88\left(\mathrm{t}, J=7.3 \mathrm{~Hz}, 3 \mathrm{H}, \mathrm{CH}_{3}\right)$, $0.95\left(\mathrm{t}, J=7.2 \mathrm{~Hz}, 3 \mathrm{H}, \mathrm{CH}_{3}\right), 1.52\left(\mathrm{~m}, 2 \mathrm{H}, \mathrm{CH}_{2}\right), 1.74(\mathrm{~m}, 2 \mathrm{H}$, $\left.\mathrm{CH}_{2}\right), 2.51\left(\mathrm{t}, J=7.3 \mathrm{~Hz}, 2 \mathrm{H}, \mathrm{SCH}_{2}\right), 3.94(\mathrm{t}, J=7.2 \mathrm{~Hz}, 2 \mathrm{H}$, $\left.\mathrm{NCH}_{2}\right), 6.09$ (m, $\left.1 \mathrm{H}, \mathrm{H}-4\right), 6.30$ (m, $\left.1 \mathrm{H}, \mathrm{H}-3\right), 6.74$ (m, $\left.1 \mathrm{H}, \mathrm{H}-5\right)$.

${ }^{13} \mathrm{C} \mathrm{NMR}\left(\mathrm{CDCl}_{3}\right): \delta=11.04\left(\mathrm{CH}_{3}\right), 12.96\left(\mathrm{CH}_{3}\right), 22.54\left(\mathrm{CH}_{2}\right)$, $24.81\left(\mathrm{CH}_{2}\right), 39.65\left(\mathrm{SCH}_{2}\right), 48.16\left(\mathrm{NCH}_{2}\right), 107.70(\mathrm{C}-4), 116.95$ (C-3), 119.95 (C-2), 122.99 (C-5).

MS (EI, $60 \mathrm{eV}): m / z(\%)=183\left(59,[\mathrm{M}]^{+}\right)\left(\right.$Lit. $\left.^{15}\right)$.

Anal. Calcd for $\mathrm{C}_{10} \mathrm{H}_{17} \mathrm{NS}$ : C, 65.52; H, 9.35; N, 7.64; S, 17.49 . Found: C, 65.67; H, 9.29; N, 7.57; S, 17.52.

\section{$\mathrm{N}$-Butyl-2-(butylsulfanyl)-1 $\mathrm{H}$-pyrrole (3d)}

To a solution of $i-\mathrm{Pr}_{2} \mathrm{NH}(15.3 \mathrm{~g}, 0.15 \mathrm{~mol}), t$-BuOK (15.6 g, 0.14 $\mathrm{mol})$, and $n$-BuLi $(0.12 \mathrm{~mol})$ in THF $(60 \mathrm{~mL})$ and hexane $(75 \mathrm{~mL})$ was added dropwise a solution of allyl isothiocyanate $(6.3 \mathrm{~g}, 0.06$ $\mathrm{mol})$ in THF $(40 \mathrm{~mL})$ during $35 \mathrm{~min}$ at -30 to $-20^{\circ} \mathrm{C}$. After stirring for $15 \mathrm{~min}$ at $42-45^{\circ} \mathrm{C}, n$-BuI $(33.2 \mathrm{~g}, 0.18 \mathrm{~mol})$ was added in one portion at $30^{\circ} \mathrm{C}$, and the reaction mixture was stirred for $40 \mathrm{~min}$ at $35-45^{\circ} \mathrm{C}$. Then, DMSO $(50 \mathrm{~mL})$ was added at $25^{\circ} \mathrm{C}$, and stirring was continued for an additional $15 \mathrm{~min}$. After carrying out the typical workup as described above, the combined organic extracts were washed with $\mathrm{H}_{2} \mathrm{O}(5 \times 30 \mathrm{~mL})$ (to free from DMSO), dried $\left(\mathrm{K}_{2} \mathrm{CO}_{3}\right)$, and concentrated under reduced pressure; light-yellow liquid; yield: $9 \mathrm{~g}(71 \%)$; bp $145-155^{\circ} \mathrm{C} / 0.5$ Torr; $n_{\mathrm{D}}{ }^{20} 1.5074$.

IR (neat): 3100, 2950, 2920, 2860, 1500, 1450, 1420, 1370, 1360, 1280, 1210, 1200, 1180, 1100, 1065, 1000, 900, 860, 780, 745, 700, $600 \mathrm{~cm}^{-1}$.

${ }^{1} \mathrm{H}$ NMR (400 MHz, $\left.\mathrm{CDCl}_{3}\right): \delta=0.86\left(\mathrm{t}, J=7.3 \mathrm{~Hz}, 3 \mathrm{H}, \mathrm{CH}_{3}\right)$, $0.91\left(\mathrm{t}, J=7.2 \mathrm{~Hz}, 3 \mathrm{H}, \mathrm{CH}_{3}\right), 1.30\left(\mathrm{~m}, 2 \mathrm{H}, \mathrm{CH}_{2}\right), 1.36(\mathrm{~m}, 2 \mathrm{H}$, $\left.\mathrm{CH}_{2}\right), 1.49\left(\mathrm{~m}, 2 \mathrm{H}, \mathrm{CH}_{2}\right), 1.69\left(\mathrm{~m}, 2 \mathrm{H}, \mathrm{CH}_{2}\right), 2.54(\mathrm{t}, J=7.3 \mathrm{~Hz}, 2$ $\left.\mathrm{H}, \mathrm{SCH}_{2}\right), 3.98\left(\mathrm{t}, J=7.2 \mathrm{~Hz}, 2 \mathrm{H}, \mathrm{NCH}_{2}\right), 6.08(\mathrm{~m}, 1 \mathrm{H}, \mathrm{H}-4), 6.29$ (m, $1 \mathrm{H}, \mathrm{H}-3), 6.73$ (m, $1 \mathrm{H}, \mathrm{H}-5)$.

${ }^{13} \mathrm{C}$ NMR $\left(\mathrm{CDCl}_{3}\right): \delta=13.46\left(\mathrm{CH}_{3}\right), 13.55\left(\mathrm{CH}_{3}\right), 19.77\left(\mathrm{CH}_{2}\right)$, $21.50\left(\mathrm{CH}_{2}\right), 31.36\left(\mathrm{CH}_{2}\right), 33.70\left(\mathrm{CH}_{2}\right), 37.39\left(\mathrm{SCH}_{2}\right), 40.25$ $\left(\mathrm{NCH}_{2}\right), 107.73$ (C-4), 116.89 (C-3), 120.82 (C-2), 122.86 (C-5).

MS (EI, $60 \mathrm{eV}): m / z(\%)=211\left(90,[\mathrm{M}]^{+}\right)\left(\right.$Lit. $\left.^{15}\right)$.

Anal. Calcd for $\mathrm{C}_{12} \mathrm{H}_{21} \mathrm{NS}$ : C, 68.19; H, 10.01; N, 6.63; S, 15.17 . Found: C, 68.23; H, 10.15; N, 6.55; S, 15.14.

\section{2-(Methylsulfanyl)-1H-pyrrole (6a); Typical Procedure}

Method A: A solution of $n$-BuLi $(0.10 \mathrm{~mol})$ in hexane $(65 \mathrm{~mL})$ was added to a stirred solution of $i-\mathrm{Pr}_{2} \mathrm{NH}(13.5 \mathrm{~g}, 0.13 \mathrm{~mol})$ and $t$-BuOK $(15.3 \mathrm{~g}, 0.14 \mathrm{~mol})$ in THF $(60 \mathrm{~mL})$ under $\mathrm{N}_{2}$ at ca. $-50{ }^{\circ} \mathrm{C}$, which was followed by dropwise addition of a solution of allyl isothiocyanate $(5.4 \mathrm{~g}, 0.05 \mathrm{~mol})$ in THF $(40 \mathrm{~mL})$ over $30 \mathrm{~min}$ at -20 to $-15{ }^{\circ} \mathrm{C}$. The resulting mixture was stirred at $45{ }^{\circ} \mathrm{C}$ for $30 \mathrm{~min}$, after which $\mathrm{H}_{2} \mathrm{O}(8 \mathrm{~g}, 0.44 \mathrm{~mol})$ was added with intensive stirring. After stirring for $20 \mathrm{~min}$ at $\sim 30^{\circ} \mathrm{C}$, MeI $(14 \mathrm{~g}, 0.10 \mathrm{~mol})$ was added in one portion and stirring was continued for $40 \mathrm{~min}$ at $50^{\circ} \mathrm{C}$. The reaction mixture was quenched with ice-water $(100 \mathrm{~mL})$ and the aqueous layer was extracted with pentane $(2 \times 30 \mathrm{~mL})$ and $\mathrm{Et}_{2} \mathrm{O}(2 \times 30$ $\mathrm{mL})$. The combined organic extracts were washed with $\mathrm{H}_{2} \mathrm{O}(3 \times 40$ $\mathrm{mL})$, dried $\left(\mathrm{K}_{2} \mathrm{CO}_{3}\right)$, concentrated under reduced pressure, and the residue distilled through a short Vigreux column; light liquid; yield: $3.7 \mathrm{~g}(66 \%)$; bp $30-40{ }^{\circ} \mathrm{C} / 0.5$ Torr; $n_{\mathrm{D}}{ }^{20} 1.5445$ (Lit. bp $87-$ $90{ }^{\circ} \mathrm{C} / 15 \mathrm{mmHg} ;{ }^{8 \mathrm{a}}$ bp $\left.60-65^{\circ} \mathrm{C} / 3 \mathrm{mmHg}^{8 \mathrm{~g}}\right)$.

IR (neat): 3370, 3100, 3050, 2960, 2900, 2860, 1520, 1420, 1410, $1400,1375,1300,1100,1070,1020,960,920,870,800,720,640$, $550 \mathrm{~cm}^{-1}$.

${ }^{1} \mathrm{H} \mathrm{NMR}\left(400 \mathrm{MHz}, \mathrm{CDCl}_{3}\right): \delta=2.26\left(\mathrm{~s}, 3 \mathrm{H}, \mathrm{SCH}_{3}\right), 6.16(\mathrm{~m}, 1 \mathrm{H}$, H-4), 6.32 (m, $1 \mathrm{H}, \mathrm{H}-3), 6.72$ (m, $1 \mathrm{H}, \mathrm{H}-5), 8.30$ (br s, $1 \mathrm{H}, \mathrm{NH})$,

${ }^{13} \mathrm{C} \mathrm{NMR}\left(\mathrm{CDCl}_{3}\right): \delta=20.94\left(\mathrm{SCH}_{3}\right), 109.62(\mathrm{C}-4), 114.61(\mathrm{C}-3)$, 119.94 (C-5), 121.03 (C-2).

MS (EI, $60 \mathrm{eV}): m / z(\%)=113\left(100,[\mathrm{M}]^{+}\right)\left(\right.$Lit. $\left.^{15}\right)$.

Anal. Calcd for $\mathrm{C}_{5} \mathrm{H}_{7} \mathrm{NS}$ : C, 53.06; H, 6.23; N, 12.38; S, 28.33 . Found: C, 53.23; H, 6.46; N, 12.45; S, 27.94.

\section{2-(Ethylsulfanyl)-1 $H$-pyrrole (6b)}

Method A: To a solution of $i$ - $\mathrm{Pr}_{2} \mathrm{NH}(14.2 \mathrm{~g}, 0.14 \mathrm{~mol}), t$-BuOK $(14.9 \mathrm{~g}, 0.13 \mathrm{~mol})$, and $n$-BuLi $(0.12 \mathrm{~mol})$ in THF $(50 \mathrm{~mL})$ and hexane $(75 \mathrm{~mL})$ was added dropwise a solution of allyl isothiocyanate $(5.4 \mathrm{~g}, 0.05 \mathrm{~mol})$ in THF $(40 \mathrm{~mL})$ during $35 \mathrm{~min}$ at -18 to $-15^{\circ} \mathrm{C}$. After stirring for $30 \mathrm{~min}$ at $35-40{ }^{\circ} \mathrm{C}, \mathrm{H}_{2} \mathrm{O}(8.7 \mathrm{~g}, 0.48 \mathrm{~mol})$ was added at $35^{\circ} \mathrm{C}$, and the mixture stirred for $25 \mathrm{~min}$ at $40-50{ }^{\circ} \mathrm{C}$. Then, EtI (11.8 g, $0.08 \mathrm{~mol})$ was added in one portion, and stirring was continued for $2 \mathrm{~h}$ at $40-45^{\circ} \mathrm{C}$. Workup as described above afforded $\mathbf{6 b}$ as a light liquid; yield: $3.7 \mathrm{~g}(58 \%)$; bp $50-60{ }^{\circ} \mathrm{C} / 0.5$ Torr; $n_{\mathrm{D}}{ }^{20} 1.5348$.

IR (neat): 3370, 3100, 3050, 2950, 2910, 2860, 1520, 1440, 1420, $1400,1370,1360,1250,1100,1070,1040,1020,960,920,870$, $800,750,720,640,550 \mathrm{~cm}^{-1}$. 
${ }^{1} \mathrm{H}$ NMR $\left(90 \mathrm{MHz}, \mathrm{CCl}_{4}\right): \delta=1.18\left(\mathrm{t}, J=7.4 \mathrm{~Hz}, 3 \mathrm{H}, \mathrm{CH}_{3}\right), 2.54$ $\left(\mathrm{q}, J=7.4 \mathrm{~Hz}, 2 \mathrm{H}, \mathrm{SCH}_{2}\right), 6.10(\mathrm{~m}, 1 \mathrm{H}, \mathrm{H}-4), 6.28(\mathrm{~m}, 1 \mathrm{H}, \mathrm{H}-3)$, 6.68 (m, $1 \mathrm{H}, \mathrm{H}-5), 8.40$ (br s, $1 \mathrm{H}, \mathrm{NH}$ ).

MS (EI, $60 \mathrm{eV}): m / z(\%)=127\left(88,[\mathrm{M}]^{+}\right)\left(\right.$Lit. $\left.^{16}\right)$.

Anal. Calcd for $\mathrm{C}_{6} \mathrm{H}_{9} \mathrm{NS}$ : C, 56.65; H, 7.13; N, 11.01; S, 25.20. Found: C, 56.77; H, 7.21; N, 10.90; S, 25.18.

\section{2-(Propylsulfanyl)-1H-pyrrole (6c)}

Method A: To a solution of $i-\mathrm{Pr}_{2} \mathrm{NH}(10.2 \mathrm{~g}, 0.10 \mathrm{~mol}), t$-BuOK $(11.5 \mathrm{~g}, 0.10 \mathrm{~mol})$, and $n$-BuLi $(0.10 \mathrm{~mol})$ in THF $(60 \mathrm{~mL})$ and hexane $(65 \mathrm{~mL})$ was added dropwise a solution of allyl isothiocyanate (5.3 g, $0.05 \mathrm{~mol})$ in THF $(40 \mathrm{~mL})$ during $40 \mathrm{~min}$ at -28 to $-25^{\circ} \mathrm{C}$. After stirring for $20 \mathrm{~min}$ at $40-43^{\circ} \mathrm{C}, \mathrm{H}_{2} \mathrm{O}(6 \mathrm{~g}, 0.33 \mathrm{~mol})$ was added at $40{ }^{\circ} \mathrm{C}$ and the mixture stirred for $15 \mathrm{~min}$ at $\sim 30^{\circ} \mathrm{C}$. Then, $n-$ PrI (14.6 g, $0.08 \mathrm{~mol})$ was added in one portion, and stirring was continued for $30 \mathrm{~min}$ at $45-55^{\circ} \mathrm{C}$. Workup as described above afforded $\mathbf{6 c}$ as a light liquid; yield: $3.8 \mathrm{~g} \mathrm{(54 \% )}$; bp $\sim 70{ }^{\circ} \mathrm{C} / 0.8$ Torr; $n_{\mathrm{D}}{ }^{20} 1.5338$.

Method B: To a solution of $i-\mathrm{Pr}_{2} \mathrm{NH}(13.4 \mathrm{~g}, 0.13 \mathrm{~mol}), t$-BuOK $(15.6 \mathrm{~g}, 0.14 \mathrm{~mol})$, and $n-\operatorname{BuLi}(0.12 \mathrm{~mol})$ in THF $(60 \mathrm{~mL})$ and hexane $(72 \mathrm{~mL})$ was added dropwise a solution of allyl isothiocyanate $(5.4 \mathrm{~g}, 0.05 \mathrm{~mol})$ in THF $(35 \mathrm{~mL})$ for $35 \mathrm{~min}$ at -30 to $-20^{\circ} \mathrm{C}$. After stirring for $10 \mathrm{~min}$ at $\sim 40^{\circ} \mathrm{C}, n-\operatorname{PrI}(11 \mathrm{~g}, 0.06 \mathrm{~mol})$ was added dropwise during $15 \mathrm{~min}$ at $\sim 30^{\circ} \mathrm{C}$ and stirred for an additional $10 \mathrm{~min}$. Then the reaction mixture was heated to $45^{\circ} \mathrm{C}$ and stirred for 30 min. The workup was carried out as described in method A; yield: $4.8 \mathrm{~g}(68 \%)$.

IR (neat): 3370, 3100, 2950, 2930, 2860, 2810, 1530, 1450, 1435 , $1410,1400,1380,1370,1335,1290,1240,1170,1110,1065,1035$, $930,900,870,830,800,775,720,650,550 \mathrm{~cm}^{-1}$.

${ }^{1} \mathrm{H}$ NMR (400 MHz, $\left.\mathrm{CDCl}_{3}\right): \delta=0.92\left(\mathrm{t}, J=7.3 \mathrm{~Hz}, 3 \mathrm{H}, \mathrm{CH}_{3}\right)$, $1.53\left(\mathrm{~m}, 2 \mathrm{H}, \mathrm{CH}_{2}\right), 2.56\left(\mathrm{t}, J=7.3 \mathrm{~Hz}, 2 \mathrm{H}, \mathrm{SCH}_{2}\right), 6.16(\mathrm{~m}, 1 \mathrm{H}$, H-4), 6.32 (m, $1 \mathrm{H}, \mathrm{H}-3), 6.74$ (m, $1 \mathrm{H}, \mathrm{H}-5), 8.40$ (br s, $1 \mathrm{H}, \mathrm{NH})$.

${ }^{13} \mathrm{C} \mathrm{NMR}\left(\mathrm{CDCl}_{3}\right): \delta=12.91\left(\mathrm{CH}_{3}\right), 23.01\left(\mathrm{CH}_{2}\right), 39.69\left(\mathrm{SCH}_{2}\right)$, 109.62 (C-4), 116.13 (C-3), 119.24 (C-2), 120.13 (C-5).

MS (EI, $60 \mathrm{eV}): m / z(\%)=141\left(50,[\mathrm{M}]^{+}\right)\left(\right.$Lit. $\left.^{16}\right)$.

Anal. Calcd for $\mathrm{C}_{7} \mathrm{H}_{11} \mathrm{NS}$ : C, 59.53; H, 7.85; N, 9.92; S, 22.70 . Found: C, 59.66; H, 7.79; N, 9.83; S, 22.78.

\section{2-(Butylsulfanyl)-1 $H$-pyrrole (6d)}

Method A: To a solution of $i$ - $\mathrm{Pr}_{2} \mathrm{NH}(15.9 \mathrm{~g}, 0.16 \mathrm{~mol}), t$-BuOK $(15.0 \mathrm{~g}, 0.13 \mathrm{~mol})$, and $n$-BuLi $(0.12 \mathrm{~mol})$ in THF $(60 \mathrm{~mL})$ and hexane $(75 \mathrm{~mL})$ was added dropwise a solution of allyl isothiocyanate $(5.3 \mathrm{~g}, 0.05 \mathrm{~mol})$ in THF $(40 \mathrm{~mL})$ for $25 \mathrm{~min}$ at -18 to $-15^{\circ} \mathrm{C}$. After stirring for $35 \mathrm{~min}$ at $40-43^{\circ} \mathrm{C}, \mathrm{H}_{2} \mathrm{O}(5.3 \mathrm{~g}, 0.29 \mathrm{~mol})$ was added at $30{ }^{\circ} \mathrm{C}$ (the temperature rose to $50^{\circ} \mathrm{C}$ ). In $5 \mathrm{~min}, n$-BuI (16.2 g, 0.09 mol) was added in one portion, and stirring was continued for 30 min at $50-65^{\circ} \mathrm{C}$. Workup as described above afforded $\mathbf{6 d}$ as a light liquid; yield: $5.3 \mathrm{~g}(68 \%)$; bp $70-80^{\circ} \mathrm{C} / 0.8$ Torr; $n_{\mathrm{D}}{ }^{20} 1.5235$.

Method B: To a solution of $i$ - $\mathrm{Pr}_{2} \mathrm{NH}(17.9 \mathrm{~g}, 0.18 \mathrm{~mol}), t$-BuOK $(16.3 \mathrm{~g}, 0.14 \mathrm{~mol})$, and $n$-BuLi $(0.12 \mathrm{~mol})$ in THF $(60 \mathrm{~mL})$ and hexane $(75 \mathrm{~mL})$ was added dropwise a solution of allyl isothiocyanate $(5.4 \mathrm{~g}, 0.05 \mathrm{~mol})$ in THF $(35 \mathrm{~mL})$ during $35 \mathrm{~min}$ at ca. $-20^{\circ} \mathrm{C}$. After stirring for $10 \mathrm{~min}$ at -20 to $0{ }^{\circ} \mathrm{C}$, then for an additional $15 \mathrm{~min}$ at $30-38^{\circ} \mathrm{C}, n$-BuI $(11.2 \mathrm{~g}, 0.06 \mathrm{~mol})$ was added dropwise for $20 \mathrm{~min}$ at $35-42{ }^{\circ} \mathrm{C}$, and stirred for an additional $40 \mathrm{~min}$. Workup was carried out as described in method A; yield: $3.6 \mathrm{~g} \mathrm{(46 \% )}$.

IR (neat): $3380,3100,2950,2920,2860,2850,1530,1460,1430$, $1400,1370,1270,1210,1110,1070,1035,930,910,880,800,720$, $650,550 \mathrm{~cm}^{-1}$.

${ }^{1} \mathrm{H}$ NMR (400 MHz, $\left.\mathrm{CDCl}_{3}\right): \delta=0.86\left(\mathrm{t}, J=7.3 \mathrm{~Hz}, 3 \mathrm{H}, \mathrm{CH}_{3}\right)$, $1.35\left(\mathrm{~m}, 2 \mathrm{H}, \mathrm{CH}_{2}\right), 1.49\left(\mathrm{~m}, 2 \mathrm{H}, \mathrm{CH}_{2}\right), 2.60(\mathrm{t}, J=7.3 \mathrm{~Hz}, 2 \mathrm{H}$, $\left.\mathrm{SCH}_{2}\right), 6.17$ (m, 1 H, H-4), 6.33 (m, $\left.1 \mathrm{H}, \mathrm{H}-3\right), 6.75$ (m, $\left.1 \mathrm{H}, \mathrm{H}-5\right)$, 8.30 (br s, $1 \mathrm{H}, \mathrm{NH})$.
${ }^{13} \mathrm{C}$ NMR $\left(\mathrm{CDCl}_{3}\right): \delta=13.70\left(\mathrm{CH}_{3}\right), 21.65\left(\mathrm{CH}_{2}\right), 32.07\left(\mathrm{CH}_{2}\right)$, $37.65\left(\mathrm{SCH}_{2}\right), 109.91(\mathrm{C}-4), 116.36(\mathrm{C}-3), 119.58(\mathrm{C}-2), 120.26(\mathrm{C}-$ $5)$.

MS (EI, $60 \mathrm{eV}): m / z(\%)=155\left(33,[\mathrm{M}]^{+}\right)\left(\right.$Lit. $\left.^{16}\right)$.

Anal. Calcd for $\mathrm{C}_{8} \mathrm{H}_{13} \mathrm{NS}$ : C, 61.89; H, 8.44; N, 9.02; S, 20.65 . Found: C, 61.95; H, 8.32; N, 9.11; S, 20.58.

\section{2-(Allylsulfanyl)-1 $\mathrm{H}$-pyrrole (6e)}

Method $A$ : To a solution of $i-\mathrm{Pr}_{2} \mathrm{NH}(13.7 \mathrm{~g}, 0.14 \mathrm{~mol}), t$-BuOK $(14.3 \mathrm{~g}, 0.13 \mathrm{~mol})$, and $n$-BuLi $(0.12 \mathrm{~mol})$ in THF $(60 \mathrm{~mL})$ and hexane $(75 \mathrm{~mL})$ was added dropwise a solution of allyl isothiocyanate $(5.3 \mathrm{~g}, 0.05 \mathrm{~mol})$ in THF $(40 \mathrm{~mL})$ for $22 \mathrm{~min}$ at -20 to $-18^{\circ} \mathrm{C}$. After stirring for $45 \mathrm{~min}$ at $40-45^{\circ} \mathrm{C}, \mathrm{H}_{2} \mathrm{O}(7.4 \mathrm{~g}, 0.41 \mathrm{~mol})$ was added at $30{ }^{\circ} \mathrm{C}$, and the mixture stirred for $20 \mathrm{~min}$ at $35-45^{\circ} \mathrm{C}$. Then, allyl bromide $(15.2 \mathrm{~g}, 0.12 \mathrm{~mol})$ was added in one portion at $30^{\circ} \mathrm{C}$, and stirring was continued for $30 \mathrm{~min}$ at $\sim 45^{\circ} \mathrm{C}$. Workup as described above afforded 6e as a light liquid; yield: $4.15 \mathrm{~g}(60 \%)$; bp 50 $60{ }^{\circ} \mathrm{C} / 0.5$ Torr; $n_{\mathrm{D}}{ }^{20} 1.5607$ (Lit. ${ }^{8 \mathrm{e}}$ bp $60{ }^{\circ} \mathrm{C} / 0.3$ Torr).

IR (neat): 3380, 3100, 3070, 2970, 2950, 2910, 1630, 1525, 1425, $1400,1220,1110,1080,1020,990,925,915,880,870,800,720$, $650,575,550 \mathrm{~cm}^{-1}$.

${ }^{1} \mathrm{H}$ NMR (400 MHz, $\left.\mathrm{CDCl}_{3}\right): \delta=3.22\left(\mathrm{~d}, J=7.3 \mathrm{~Hz}, 2 \mathrm{H}, \mathrm{SCH}_{2}\right)$, $4.92\left(\mathrm{dd}, J_{\text {cis }}=9.9 \mathrm{~Hz}, J_{\text {gem }}=1.1 \mathrm{~Hz}, 1 \mathrm{H}, \mathrm{CH}_{2}=\right), 4.98(\mathrm{dd}$, $\left.J_{\text {trans }}=17.1 \mathrm{~Hz}, 1 \mathrm{H}, \mathrm{CH}_{2}=\right), 5.84(\mathrm{~m}, 1 \mathrm{H}, \mathrm{CH}=), 6.16(\mathrm{~m}, 1 \mathrm{H}, \mathrm{H}-$ 4), 6.34 ( $\mathrm{m}, 1 \mathrm{H}, \mathrm{H}-3), 6.76(\mathrm{~m}, 1 \mathrm{H}, \mathrm{H}-5), 8.30$ (br s, $1 \mathrm{H}, \mathrm{NH})$.

${ }^{13} \mathrm{C} \mathrm{NMR}\left(\mathrm{CDCl}_{3}\right): \delta=41.20\left(\mathrm{SCH}_{2}\right), 109.84(\mathrm{C}-4), 116.71(\mathrm{C}-3)$, $117.37\left(\mathrm{CH}_{2}=\right), 118.77(\mathrm{C}-2), 120.63(\mathrm{C}-5), 134.66(\mathrm{CH}=)$.

MS (EI, $60 \mathrm{eV}): m / z(\%)=139\left(77,[\mathrm{M}]^{+}\right)\left(\right.$Lit. $\left.^{16}\right)$.

Anal. Calcd for $\mathrm{C}_{7} \mathrm{H}_{9} \mathrm{NS}$ : C, 60.39; H, 6.52; N, 10.06; S, 23.03. Found: C, 60.17; H, 6.70; N, 10.29; S, 22.94.

\section{2-(2-Propynylsulfanyl)-1 $H$-pyrrole (6f)}

Method A: To a solution of $i-\mathrm{Pr}_{2} \mathrm{NH}(13.5 \mathrm{~g}, 0.13 \mathrm{~mol}), t$-BuOK $(14.3 \mathrm{~g}, 0.13 \mathrm{~mol})$, and $n$-BuLi $(0.11 \mathrm{~mol})$ in THF $(50 \mathrm{~mL})$ and hexane $(70 \mathrm{~mL})$ was added dropwise a solution of allyl isothiocyanate $(5.3 \mathrm{~g}, 0.05 \mathrm{~mol})$ in THF $(35 \mathrm{~mL})$ for $20 \mathrm{~min}$ at -15 to $-10^{\circ} \mathrm{C}$. After stirring for $25 \mathrm{~min}$ at $40-45^{\circ} \mathrm{C}, \mathrm{H}_{2} \mathrm{O}(8.3 \mathrm{~g}, 0.46 \mathrm{~mol})$ was added at $40{ }^{\circ} \mathrm{C}$, and the mixture stirred for $10 \mathrm{~min}$ at $45-53^{\circ} \mathrm{C}$. Then, propargyl iodide $(12.5 \mathrm{~g}, 0.08 \mathrm{~mol})$ was added in one portion at $35^{\circ} \mathrm{C}$, and stirring was continued for $30 \mathrm{~min}$ at $\sim 45^{\circ} \mathrm{C}$. Workup as described above afforded 6 f as a light liquid; yield: $3.2 \mathrm{~g}(47 \%)$; bp $\sim 60{ }^{\circ} \mathrm{C} / 0.5$ Torr; $n_{\mathrm{D}}{ }^{20} 1.5847$.

IR (neat): $3400,3280,3100,2950,2910,1525,1425,1400,1220$, $1110,1070,1020,925,880,870,800,720,680,635,540 \mathrm{~cm}^{-1}$.

${ }^{1} \mathrm{H}$ NMR $\left(400 \mathrm{MHz}, \mathrm{CDCl}_{3}\right): \delta=2.24(\mathrm{t}, J=2.4 \mathrm{~Hz}, 1 \mathrm{H}, \equiv \mathrm{CH})$, $3.27\left(\mathrm{~d}, J=2.4 \mathrm{~Hz}, 2 \mathrm{H}, \mathrm{SCH}_{2}\right), 6.18(\mathrm{~m}, 1 \mathrm{H}, \mathrm{H}-4), 6.44(\mathrm{~m}, 1 \mathrm{H}$, H-3), 6.79 (m, $1 \mathrm{H}, \mathrm{H}-5), 8.48$ (br s, $1 \mathrm{H}, \mathrm{NH})$.

${ }^{13} \mathrm{C}$ NMR $\left(\mathrm{CDCl}_{3}\right): \delta=26.24\left(\mathrm{SCH}_{2}\right), 72.36(\equiv \mathrm{CH}), 80.98(\mathrm{C} \equiv)$, 110.01 (C-4), 117.24 (C-3), 117.85 (C-2), 121.48 (C-5).

MS (EI, $60 \mathrm{eV}): m / z(\%)=137\left(66,[\mathrm{M}]^{+}\right)\left(\right.$Lit. $\left.^{16}\right)$.

Anal. Calcd for $\mathrm{C}_{7} \mathrm{H}_{7} \mathrm{NS}$ : C, 61.28; H, 5.14; N, 10.21; S, 23.37 . Found: C, 61.24; H, 5.09; N, 10.08; S, 23.63.

\section{Acknowledgment}

The authors are grateful for the financial support from the Russian Foundation for Basic Research (Grant No. 09-03-00890a) and the Presidium of the Russian Academy of Sciences (Project No. 8.17).

Supporting Information for this article is available online at http://www.thieme-connect.com/ejournals/toc/synthesis. 


\section{References}

(1) (a) Comprehensive Heterocyclic Chemistry III; Vol. 3; Katritzky, A. R.; Ramsden, C. A.; Scriven, E. F. V.; Taylor, R. J. K., Eds.; Elsevier: Amsterdam, 2008. (b) Wood, T. E.; Thompson, A. Chem. Rev. 2007, 107, 1831. (c) Fan, H.; Peng, J.; Hamann, M. T.; Hu, J.-F. Chem. Rev. 2008, 108, 264. (d) Ferreira, V. F.; de Souza, M. C. B. V.; Cunha, A. C.; Pereira, L. O. R.; Ferreira, M. L. G. Org. Prep. Proced. Int. 2001, 33, 411. (e) Electronic Materials: The Oligomer Approach; Müllen, K.; Wegner, G., Eds.; Wiley-VCH: Weinheim, 1997. (f) Loudet, A.; Burgess, K. Chem. Rev. 2007, 107, 4891. (g) Mack, J.; Kobayashi, N. Chem. Rev. 2011, 111, 281. (h) Heinze, J.; Frontana-Uribe, B. A.; Ludwigs, S. Chem. Rev. 2010, 110, 4724.

(2) (a) Kang, J.-G.; Cho, H.-K.; Park, C.; Kang, S. K.; Kim, I. T.; Lee, S. W.; Lee, H. H.; Lee, Y. N.; Cho, S. H.; Lee, J. H.; Lee, S. H. Bull. Korean Chem. Soc. 2008, 29, 679. (b) Li, H.; Lambert, C.; Stahl, R. Macromolecules 2006, 39, 2049. (c) Alemán, C.; Domingo, V. M.; Julia, L. J. Phys. Chem. A. 2001, 105, 5266. (d) Rosa, A.; Ricciardi, G.; Baerends, E. J.; Zimin, M.; Rodgers, M. A. J.; Matsumoto, S.; Ono, N. Inorg. Chem. 2005, 44, 6609. (e) Campiani, G.; Nacci, V.; Bechelli, S.; Ciani, S. M.; Garofalo, A.; Fiorini, I.; Wikström, H.; de Boer, P.; Liao, Y.; Tepper, P. G.; Cagnotto, A.; Mennini, T. J. Med. Chem. 1998, 41, 3763. (f) Cherkofsky, S. C. Eur. Pat. Appl EP 005156 A119791114, 1979; Chem. Abstr. 1980, 93, 8007. (g) Uetake, T.; Nishikawa, M.; Tada, M. J. Chem. Soc., Perkin Trans. 1 1997, 3591. (h) Thompson, A.; Butler, R. J.; Grundy, M. N.; Laltoo, A. B. E.; Robertson, K. N.; Cameron, T. S. J. Org. Chem. 2005, 70, 3753; and references cited therein.

(3) (a) Gillis, H. M.; Greene, L.; Thompson, A. Synlett 2009, 112. (b) Yin, G.; Wang, Z.; Chen, A.; Gao, M.; Wu, A.; Pan, Y. J. Org. Chem. 2008, 73, 3377. (c) Misra, N. C.; Panda, K.; Ila, H.; Junjappa, H. J. Org. Chem. 2007, 72, 1246. (d) Mitamure, T.; Iwata, K.; Ogawa, A. J. Org. Chem. 2011, 76,3880 .

(4) (a) Jha, M.; Enaohwo, O.; Guy, S. Tetrahedron Lett. 2011, 52, 684. (b) Martino, G. D.; Edler, M. C.; Regina, G. L.; Coluccia, A.; Barbera, M. C.; Barrow, D.; Nicholson, R. I.; Chiosis, G.; Brancale, A.; Hamel, E.; Artico, M.; Silvestri, R. J. Med. Chem. 2006, 49, 947. (c) Berlin, A.; Pagani, G. A.; Schiavon, G.; Zotti, G. J. Chem. Soc., Perkin Trans. 2 1990, 699. (d) Zotti, G.; Schiavon, G.; Berlin, A.; Pagani, G. Synth. Met. 1989, 28, C183. (e) Semmelhack, M. F.; Chlenov, A.; Ho, D. M. J. Am. Chem. Soc. 2005, 127, 7759. (f) Groenendaal, L.; Pieterse, K.; Vekemans, J. A. J. M.; Meijer, E. W. Synth. Commun. 1997, 27, 257. (g) Boiadjiev, S. E.; Lightner, D. A. J. Org. Chem. 1998, 63, 6220. (h) Domingo, V. M.; Brillas, E.; Torrelles, X.; Rius, J.; Julia, L. J. Org. Chem. 2001, 66, 8236.

(5) (a) Muresan, A. Z.; Thamyongkit, P.; Diers, J. R.; Holten, D.; Lindsey, J. S.; Bocian, D. F. J. Org. Chem. 2008, 73, 6947. (b) Garabatos-Perera, J. R.; Rotstein, B. H.; Thompson, A. J. Org. Chem. 2007, 72, 7382.

(c) Thamyongkit, P.; Bhise, A. D.; Taniguchi, M.; Lindsey, J. S. J. Org. Chem. 2006, 71, 903. (d) Jolicoeur, B.; Chapman, E. E.; Thompson, A.; Lubell, W. D. Tetrahedron 2006, 62, 11531.

(6) (a) Sommen, G. L.; Comel, A.; Kirsch, G. Synth. Commun. 2005, 35, 693. (b) Antipin, R. L.; Chernysheva, A. N.; Beloglazkina, E. K.; Zyk, N. V. Chem. Heterocycl. Compd. 2010, 46, 1071. (c) Katritzky, A. R.; Wang, X.; Denisenko,
A. J. Org. Chem. 2001, 66, 2850. (d) Gupta, A. K.; Reddy, K. R.; Ila, H.; Junjappa, H. J. Chem. Soc., Perkin Trans. 1 1995, 1725. (e) Peng, L.; Zhang, X.; Ma, J.; Zhong, Z.; Wang, J. Org. Lett. 2007, 9, 1445. (f) Kumar, A.; Ila, H.; Junjappa, H. J. Chem. Soc., Chem. Commun. 1976, 593.

(7) (a) Nedolya, N. A.; Brandsma, L.; Trofimov, B. A. Chem. Heterocycl. Compd. 1996, 32, 781. (b) Nedolya, N. A.; Brandsma, L.; Trofimov, B. A. Russ. J. Gen. Chem. 1996, 66, 1986. (c) Tarasova, O. A.; Nedolya, N. A.; Vvedensky, V. Yu.; Brandsma, L.; Trofimov, B. A. Tetrahedron Lett. 1997, 38, 7241. (d) Nedolya, N. A.; Brandsma, L.; Tarasova, O. A.; Verkruijsse, H. D.; Trofimov, B. A. Tetrahedron Lett. 1998, 39, 2409. (e) Brandsma, L.; Nedolya, N. A.; Trofimov, B. A. Eur. J. Org. Chem. 1999, 2663. (f) Brandsma, L.; Nedolya, N. A.; Verkruijsse, H. D.; Trofimov, B. A. Chem. Heterocycl. Compd. 2000, 36, 876. (g) Brandsma, L.; Nedolya, N. A.; Trofimov, B. A. Russ. Chem. Bull. 2000, 49, 1634. (h) Brandsma, L.; Nedolya, N. A.; Tolmachev, S. V.; Albanov, A. I. Chem. Heterocycl. Compd. 2001, 37, 364. (i) Nedolya, N. A.; Brandsma, L.; Shlyakhtina, N. I.; Tolmachev, S. V. Chem. Heterocycl. Compd. 2001, 37, 366. (j) Brandsma, L.; Nedolya, N. A.; Tolmachev, S. V. Chem. Heterocycl. Compd. 2002, 38, 54. (k) Nedolya, N. A.; Brandsma, L.; Tolmachev, S. V. Chem. Heterocycl. Compd. 2002, 38, 745. (1) Nedolya, N. A.; Brandsma, L. Russ. J. Org. Chem. 2003, 39, 609.

(m) Nedolya, N. A.; Brandsma, L. Russ. J. Org. Chem. 2006, 42, 607. (n) Nedolya, N. A.; Tarasova, O. A.; Albanov, A. I.; Klyba, L. V.; Trofimov, B. A. Chem. Heterocycl. Compd. 2010, 46, 61. (o) Tarasova, O. A.; Nedolya, N. A.; Albanov, A. I.; Trofimov, B. A. Russ. J. Org. Chem. 2010, 46, 773.

(8) (a) Gronowitz, S.; Hörnfeldt, A. B.; Gestblom, B.; Hoffman, R. A. J. Org. Chem. 1961, 26, 2615. (b) Gronowitz, S.; Hörnfeldt, A. B.; Gestblom, B.; Hoffman, R. A. Arkiv Kemi 1961, 18, 151. (c) Olsen, R. K.; Snyder, H. R. J. Org. Chem. 1963, 28, 3050. (d) Haas, A.; Niemann, U. Chem. Ber. 1977, 110, 67. (e) Teo, K.-E.; Barnett, G. H.; Anderson, H. J.; Loader, C. E. Can. J. Chem. 1978, 56, 221. (f) Carmona, O.; Greenhouse, R.; Landeros, R.; Muchowski, J. M. J. Org. Chem. 1980, 45, 5336. (g) Franco, F.; Greenhouse, R.; Muchowski, J. M. J. Org. Chem. 1982, 47, 1682. (h) Kakushima, M.; Frenette, R. J. Org. Chem. 1984, 49, 2025.

(9) (a) Nedolya, N. A. Ph.D. Dissertation; Utrecht University: The Netherlands, 1999. (b) Trofimov, B. A. J. Heterocycl. Chem. 1999, 36, 1469. (c) Brandsma, L.; Nedolya, N. A.; Tarasova, O. A.; Trofimov, B. A. Chem. Heterocycl. Compd. 2000, 36, 1241. (d) Brandsma, L. Eur. J. Org. Chem. 2001, 4569. (e) Brandsma, L.; Nedolya, N. A. Synthesis 2004, 735. (f) Nedolya, N. A. Chem. Heterocycl. Compd. 2008, 44, 1165. (g) Trofimov, B. A.; Nedolya, N. A. In Comprehensive Heterocyclic Chemistry III; Vol. 3; Katritzky, A. R.; Ramsden, C. A.; Scriven, E. F. V.; Taylor, R. J. K., Eds.; Elsevier: Amsterdam, 2008, 45.

(10) Brandsma, L.; Nedolya, N. A.; Trofimov, B. A. Russ. Chem. Bull. 1998, 47, 187.

(11) (a) Nedolya, N. A.; Brandsma, L.; Verkruijsse, H. D.; Trofimov, B. A. Tetrahedron Lett. 1997, 38, 7247. (b) Brandsma, L.; Nedolya, N. A.; Trofimov, B. A. Dokl. Chem. 1998, 358, 12. (c) Nedolya, N. A.; Brandsma, L.; Trofimov, B. A. Russ. J. Org. Chem. 1998, 34, 900.

(12) Brandsma, L.; Verkruijsse, H. Preparative Polar Organometallic Chemistry; Vol. 1; Springer-Verlag: Berlin, 1987. 
(13) Nedolya, N. A.; Brandsma, L.; van der Kerk, A. C. H. T. M.; Afonin, A. V.; de Lang, R.-J.; Trofimov, B. A. Russ. J. Gen. Chem. 1997, 67, 656 .

(14) Gharpure, M.; Stoller, A.; Bellamy, F.; Firnau, G.; Snieckus, V. Synthesis 1991, 1079.
(15) Klyba, L. V.; Bochkarev, V. N.; Brandsma, L.; Nedolya, N. A.; Trofimov, B. A. Russ. Chem. Bull. 2001, 50, 2390.

(16) Klyba, L. V.; Bochkarev, V. N.; Brandsma, L.; Nedolya, N. A.; Trofimov, B. A. Russ. J. Gen. Chem. 1999, 69, 1805. 